\title{
A benchmarking model for the customer order flow in semi-processing industries
}

\author{
I.P. Tatsiopoulos, T. Katsikas and F. Clave \\ NTU Athens, Mechanical Engineering Dept., 15780 Zografos, Greece \\ itat@central.ntua.gr \\ ELVAL S.A., Greece \\ GRAI/LAP, University of Bordeaux
}

\begin{abstract}
The non-ferrous metal industry is representative of the "implosive" industries in which a very small number of bulk material varieties is converted into a large number of product varieties. The main goal of this work is to demonstrate the approach for benchmarking the critical business process of Customer Order Flow at two pilot user sites, i.e. ELVAL (GR) and TUBUSMETALL (D) through the development and use of performance models. The approach used for building the Benchmarking Model combines three methodologies coming from different science fields, i.e. the systems analysis field (ECOGRAI performance modelling), the cost accounting field (Activity Based Costing) and the engineering economics field (productivity-driven approach).
\end{abstract}

Key
Benchmarking, Performance Modelling.

\section{Keywords}

\section{INTRODUCTION}

This is an account of work done within the benchmarking part of the Esprit Project REALMS (Reengineering Application Using Modelling and Simulation). Among the possible set of processes that represent material/information flows across the logistics chain, the Customer Order Flow (Rolstadas, 1993) has been chosen in this project as been the most critical from the pilot users' point of view, in order to be the subject of business modelling and reengineering.

The Customer Orders Flow considers the logistics chain from the customer's request to the delivery of the product. It involves and cuts across the Sales, Costing, 
Product Development, Production Planning, Materials Management and Shipping functions of both Pilot Industrial Users. The two Pilots are absolutely complementary across the value chain in the specific user sector of semi-processing of non-ferrous metals (see Table 1 for their typological attributes). ELVAL (GR) is a producer and supplier of semi-processed aluminium products, while TUBUSMETALL (D) is a wholesaler of non-ferrous products and a producer of components using semi-processed raw materials. For both of them the Customer Order Flow is of utter importance due to the vast number of product varieties according to customer requirements.

Table 1. Typological attributes of the industrial pilots

\begin{tabular}{|c|c|c|}
\hline ATTRIBUTES & ELVAL & TUBUS \\
\hline $\begin{array}{l}\text { 1. PRODLCI } \\
\text { STANDARDI- } \\
\text { SATION }\end{array}$ & $\begin{array}{l}\text { Products to } \\
\text { customers' } \\
\text { specifications }\end{array}$ & $\begin{array}{l}\text { Products to } \\
\text { customers' } \\
\text { specifications }\end{array}$ \\
\hline $\begin{array}{l}\text { 2. PRODICT } \\
\text { STRUCTURE }\end{array}$ & $\begin{array}{l}\text { Implosion } \\
\text { industry }\end{array}$ & $\begin{array}{l}\text { Implosion } \\
\text { industry }\end{array}$ \\
\hline 3. PRODUCT TYPE & $\begin{array}{l}\text { Industrial } \\
\text { Goods }\end{array}$ & Industrial Goods \\
\hline $\begin{array}{l}\text { 4. PRODUCTION } \\
\text { TRIGGER }\end{array}$ & $\begin{array}{l}\text { Make to Order } \\
\text { (MTO) }\end{array}$ & Finish to Order \\
\hline $\begin{array}{l}\text { 5. PROCUREMNT } \\
\text { STRUCTURE: }\end{array}$ & $\begin{array}{l}\text { Vertical } \\
\text { production }\end{array}$ & $\begin{array}{l}\text { Extensive } \\
\text { outsourcing }\end{array}$ \\
\hline $\begin{array}{l}\text { 6. PROCESS FLOW } \\
\text { (TIME } \\
\text { DIMENSION) }\end{array}$ & $\begin{array}{l}\text { Batch } \\
\text { production }\end{array}$ & Batch Production \\
\hline $\begin{array}{l}\text { 7. PROCESS } \\
\text { 1.AYOUT (SPACE: } \\
\text { DIMENSION) }\end{array}$ & Flow shop & Job shop \\
\hline $\begin{array}{l}\text { 8. LOGISTICS } \\
\text { STRUCIURE }\end{array}$ & $\begin{array}{l}\text { Single } \\
\text { plant/single } \\
\text { wharehouse } \\
\text { system }\end{array}$ & $\begin{array}{l}\text { Production/ } \\
\text { Distribution } \\
\text { system }\end{array}$ \\
\hline $\begin{array}{l}\text { 9. STZE } \\
(\mathrm{P}=\text { Personnel) }\end{array}$ & $\begin{array}{l}\text { Large firm } \\
(\mathrm{P}>500)\end{array}$ & $\begin{array}{l}\text { Medium-sized } \\
\text { firm }(50<\mathrm{P}<500)\end{array}$ \\
\hline
\end{tabular}

\section{APPROACH}

The approach used in the REALMS project for building the Benchmarking Model combines three methodologies coming from different science fields, i.e. the systems analysis field (ECOGRAI performance modelling), the cost accounting field (Activity Based Costing) and the engineering economics field (productivity-driven approach): 
1. As an overall methodology the GIM (GRAI Integrated Methodology, Doumeingts, 1984) and in particular the ECOGRAI component of GIM (Doumeingts et al, 1995) is used for building systems of performance indicators associated to the objectives and decision variables of business processes.

2. The Activity Based Costing (ABC) methodology (Berliner, 1989, Innes \& Mitchell, 1990, Cooper and Kaplan, 1991, Theeuwes and Adriaansen, 1994) is a well known cost accounting approach. The REALMS project included a proposed framework for using $\mathrm{ABC}$ in business process reengineering projects by connecting to defined cost drivers and overhead allocation to business process modelling (Tatsiopoulos et al, 1996).

3. The productivity-driven NTUA approach is a short-term profitability-based modelling approach to evaluate changes in output and in productivity (Cosmetatos, 1996).

In applying the three above methodologies for benchmarking the following basic steps are needed:

Step 1 compares the business practices used for performing the customer order flow process and its critical activities by ELVAL and TUBUSMETALL. The process activities have been previously analysed (REALMS Consortium - WP2, 1996).

Step 2 develops a Performance Model for the selected Business Process. The performance measurement tool used is the ECOGRAI methodology to define performance drivers (time, quality, cost/productivity) in relation to the objectives and the decision variables of the business process.

Step 3 validates the activities of step 1 through collecting performance measurement data. Those data are based on the benchmarking model of performance indicators and are collected with the help of the Benchmarking Questionnaires.

\subsection{Comparison of business practices}

The critical activities of the two pilots are nect described, i.e. of ELVAL (GR), a producer and supplier of semi-processed aluminium products and TUBUSMETALL (D), a wholesaler of non-ferrous products and a producer of components using semi-processed raw materials (Figure 1).

\section{Critical activities of TUBUSMETALL}

- What is the right price? To define the lowest permissible price and the earliest possible delivery date

- To find ways to satisfy the customer request. Important is to keep the customer. If they cannot produce or trade they outsource manufacturing or trade.

- To know from which Customer Order they earn money and from which they loose money

- To decide if enough quantity of raw material is available.

- To combine customer orders into production orders. This influences production costs (e.g. setup cost).

- To minimize scrap through solving the cutting stock problem

- Service center: to produce products that are not in the market. 
- To outsource special products means to release more capacity for standard products with lower cost.

\section{The logistics chain}

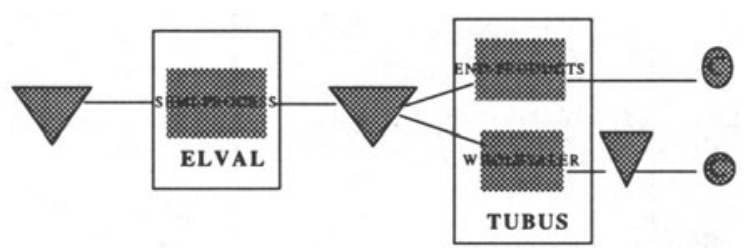

Figure 1. The logistics chain of the two pilot users

\section{Critical activities of ELVAL}

- What is the right delivery date? Delivery date assignment strategies.

- The least expensive way to produce an alloy

- To allocate raw material. That is to take make or buy decisions for the aluminum slabs that feed the hot rolling unit. Either to make them in the casting unit or to buy them from external suppliers.

- Where to stock in the logistics chain? (raw materials, intermediate products, exfactory finished products, finished stock in distribution centres near the customer?

- To process internal packing lists. A "blocking factor" is measured, i.e. if all the batches ordered by a customer are ready for shipment. This is similar to the final assembly problem in discrete manufacturing and serious time losses may occur.

- Detailed cost estimation

\section{Comparison of ELVAL and TUBUSMETALL customer order flow processes}

A comparison of the Customer Order Flow activities in the two companies (Table 1) has shown that the activity "A2. to manage stock" of TUBUS is included in the activity "A2. to process the C.O." of ELVAL. The activity "A3. to process the C.O." of TUBUS includes the activity "A3. to produce \& pack" of ELVAL. The activity "A4. to prepare the delivery" of TUBUS includes the activity "to pack". The rest of differences and similarities is shown in Table 2.

Table 2. Comparison of business processes

\begin{tabular}{|l|l|}
\hline ELVAL & TUBUSMETALL \\
\hline $\begin{array}{l}\text { A1.To create C.O. } \\
\text { Existence of blanket } \\
\text { orders }\end{array}$ & $\begin{array}{l}\text { AI. To create } \text { C. } 0 . \\
\text { No blanket orders }\end{array}$ \\
\hline
\end{tabular}




\begin{tabular}{|c|c|}
\hline $\begin{array}{l}\text { - If they cannot produce } \\
\text { they refuse the customer } \\
\text { request } \\
\text { - Price assignment is based } \\
\text { on detailed standard cost } \\
\text { estimation } \\
\text { - Importance of the } \\
\text { Delivery Lead Time } \\
\text { assignment strategy } \\
\text { - Separate processes in } \\
\text { ELVAL "to study the } \\
\text { technical feasibility" } \\
\text { (Engineering design and } \\
\text { tooling of special } \\
\text { products. }\end{array}$ & $\begin{array}{l}\text { or trade they outsource } \\
\text { trading or production } \\
\text { - Price assignment is } \\
\text { heavily customer- } \\
\text { oriented (need for } \\
\text { Activity Based Costing) } \\
\text { - Importance of the } \\
\text { reliability of delivery } \\
\text { due date, not the lead } \\
\text { time (too short) } \\
\text { In Tubusmetall it is } \\
\text { included in "to } \\
\text { precise inquiry" }\end{array}$ \\
\hline A2. To process C.O. & A2. To manage stock \\
\hline $\begin{array}{l}\text { A3. To produce \& pack } \\
\text { - Manufacturing centre }\end{array}$ & $\begin{array}{l}\text { A3. To process the C.O. } \\
\text { - Service centre }\end{array}$ \\
\hline A4. To prepare the delivery & $\begin{array}{l}\text { A4. To prepare the } \\
\text { delivery }\end{array}$ \\
\hline
\end{tabular}

\subsection{Performance model for the selected business process}

The performance model includes a system of key indicators:

1. Operational indicators concerning time-based and process quality performance measurement (Zuelch et al, 1995). For the business process and its critical activities chosen in this project (customer order flow and delivery date/price assignment decisions) this translates into indicators having to do with delivery lead times (timebased) and their deviations (process quality). Another class of quality indicators is the reliability of cost and price estimations used to respond to customer requests.

2. Cost drivers and their reciprocal cost rates developed using the Activity Based Costing technique $(\mathrm{ABC})$. The activities of $\mathrm{ABC}$ coincide to the activities of the activity model developed with GIM, thus making easier communication and integration of the key indicators model (Tatsiopoulos et al, 1996). For the Customer Order Flow process, the $\mathrm{ABC}$ technique leads to a more fair distribution of overhead costs to customer orders that either require special products/customers or small batch quantities, compared to whatever is considered a standard product or a normal batch quantity ordered. This permits a better assignment of product prices.

3. Productivity-driven indices of the Customer Order Flow process help to evaluate changes in sales output caused by accepted customer orders and changes in 
productivity caused by the treatment of those customer orders (e.g. manufacturing or outsourcing) using a profitability-based modelling approach. Those indices are based on variable cost calculations, that help to define product profit contributions and profitable customer orders ,and therefore they are complementary to the ABC cost drivers that deal with the distribution of fixed costs in pricing decisions (Eilon \& Cosmetatos 1977, Cosmetatos \& Eilon 1981, 1983, Cosmetatos in REALMS-WP3 (1996).

\section{THE ECOGRAI BENCHMARKING MODEL}

The following objectives, decision variables and performance indicators have come out of the Synthesis Group of ELVAL users.

\subsection{Activity Index for the Customer Order Flow Process in ELVAL}

A0 Customer Order Flow Process

A1 To create a customer order (C.O)

A11 To precise the request

A111 Identification of basic technical information

A12 To study the technical feasibility

A121 To check if the specs correspond to a standard product.

A13 To define the price and the delivery date

A131 To define a production date and calculate cost

A132 To check the acceptability of the date

A133 To calculate a delivery date and price

A134 To negotiate date and price with the customer

A135 To negotiate date inside the company

A14 To confirm the customer order

A15 To process blanket orders

A2 To process the C.O. in the production dept.

A21 To release production orders

A22 To produce work sheets

A23 To allocate raw material

A24 To order raw material for the casting unit

A25 To order raw material for the rolling unit

A3 To produce and pack

A4 To manage the delivery

A41 To process internal packing lists

A42 To prepare delivery documents

A43 To prepare the transportation

A44 To deliver ex-factory 


\section{Global objectives of A0 ("Customer Order Flow Process")}

GO1: To increase the profitability

GO2: To keep (or to lower) the cost and to keep at least the estimated cost

GO3: To reduce the delivery time and gain a time-based competitive edge

GO4: To deliver the agreed quality and to maximise the quality level

GO5: To deliver the order on time promised and to keep at least the estimated lead time

\section{Objectives of activity A1 ("to create a customer order")}

O1.1: To fill the the capacity

01.2: To sell with the highest possible price

01.3: To satisfy the customer requirements in terms of delivery time

01.4: To reduce the time to create the Customer Order (C.O.)

01.5: To have the right estimation in terms of cost \& delivery time

01.6: To identify the right customer specifications

01.7: To make the deal

Objectives of activity A13 ("to define price and delivery date")

O1.3.2.1 Not to overload (internal agreement)

O1.3.3.1 To calculate the right Delivery Date

O1.3.3.2 To calculate the right price

O1.3.3.3 To perform the calculation in minimum time

O1.3.4.1 To negotiate the difference between the proposals \& the negotiated results on price and Delivery Date

O1.3.4.2 To reduce the negotiation time

O1.3.5.1 To negotiate the feasibility of the production

O1.3.5.2 To propose an alternative delivery date

O1.3.5.3 To fill the capacity

O1.3.5.4 To reduce the negotiation time

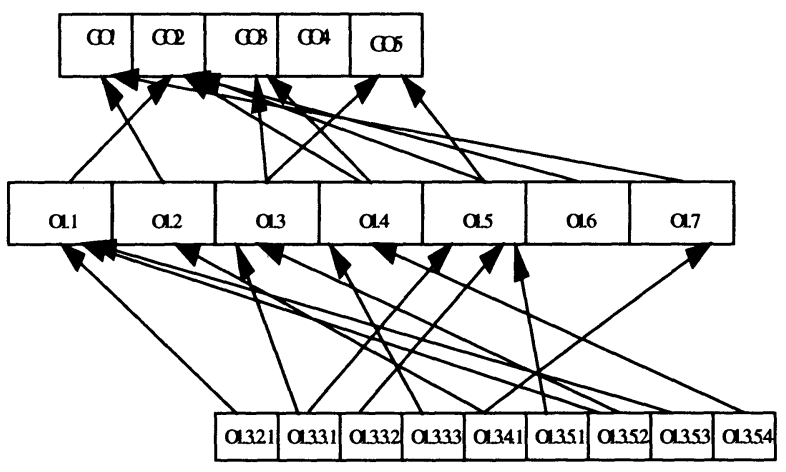

Figure 2. Coherence analysis of objectives

Decision Variables of $\mathrm{A0}$ (Customer Order Flow) 
DV1: Customer Order Promising decisions that affect the monetary value (turnover) and the profitability of the Sales Plan and the Master Production Schedule (output mix) in three kinds of ways: (a) Increase or decrease sales/production volume (change in its size only) keeping the product mix and technical specifications unchanged, (b) Change in the product mix only, (c) Change in product specifications only (e.g. produce more advanced products).

DV2: Decisions that affect the input mix of production factors (material, labour, capital, energy) and/or specifications of the inputs (e.g.,to buy slabs for hot rolling instead of using the labour and capital of the casting unit).

DV3: Decisions that increase the productivity of some inputs without adversely affecting the productivity of other inputs (e.g. to accelerate customer order flow through better production planning \& control or to shorten lead times through elimination of non-value adding activities).

Performance Indicators of A0 (Customer Order Flow)

PI1: $\quad$ P/D Ratio, where $P=($ total supply chain lead time $)$ and $D=($ delivery time requested by the cuctomers)

PI2: Index on the effect of master plan changes on the sales turnover

PI3: Index on the effect of master plan changes on the cost

PI4: Index on the effect of master plan changes on the profit

PI5: Index on the effect of input mix changes on input usage levels

PI6: Index on the effect of input mix changes on the cost

PI7: Index on the effect of input mix changes on the profit

PI8: Value Added Ratio = (Total supply chain value-adding time $)$ - $($ Total supply chain lead time)

\begin{tabular}{|c|c|c|c|c|c|c|c|c|}
\hline G01 & + & & & & & & & + \\
\hline GO2 & & & ++ & & + & ++ & & + \\
\hline \multicolumn{9}{|l|}{ G03 } \\
\hline G04 & & + & & ++ & & & ++ & + \\
\hline G05 & ++ & & & & & & & ++ \\
\hline & PII & PI2 & PI3 & PI4 & PI5 & PI6 & PI7 & PIS \\
\hline DV1 & & ++ & ++ & ++ & & & & \\
\hline DV2 & ++ & & & & ++ & ++ & ++ & \\
\hline DV3 & + & & & & ++ & ++ & ++ & ++ \\
\hline
\end{tabular}

Table 3. Coherence panel of performance indicators

\section{RESULTS ON LEAD TIMES}

Here follows the presentation of benchmarking results in the two industrial pilots, ELVAL and TUBUSMETALL concerning the performance indicators PI1 (P/D 
Ratio) and PI8 (Value Added Ratio) of global activity A0 (Customer Order Flow). According to the coherence panel of Table 3, these important time-based indicators have a profound influence on global objectives GO5 (PI1 and PI8)) and decision variables DV2 (PI1) and DV3 (PI8).

\subsection{Lead time measures}

Lead time or throughput time is a measure of the speed to execute an input through a process into a delivered output and includes all processing, setup, waiting, moving and storage times. Lead time can be measured in a variety of ways for different processes. For the overall supply chain lead time of manufacturing products, the following lead time ratios are particularly suitable.

P:D Ratio. The time extending from the placement of the supply orders through manufacturing to the delivery of finished product to the customer should be aimed to be equal or less than the customer's expected delivery lead time.

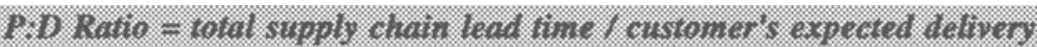
lead time.

where P:D Ratio goal <= 1

This definition measures a multiple of internal lead time over customer lead time. The goal of the lead time measure is a value less than one, meaning the production system can supply product to the customer's order without the need for forecasts or excess inventory. For companies that produce custom products to customer orders and therefore quote lead times in weeks or months, the denominator can be modified to be either the customer-desired delivery lead time or the best industry-competitor lead time.

Value added ratio. The value-added measure is an indicator of the effectiveness of a process relative to its potential. Value-added time is the "processing" time where activities are performed on the product that the customer (if it were known they were being done) would be willing to pay for. A lot of time is usually lost quite needlessly, costing visible amounts of money that contribute no value to the process. Setting value-added time in relation to available time is often a highly illustrative way of discovering how time is used in an organization.

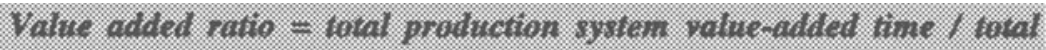
supply chain lead lime.

where Value-added ratio goal $=1$

\subsection{Benchmarking results}

The following tables 4 an 5 show the lead-time benchmarking results of the two pilots: 
Table 4. Results in TUBUSMETALL

\begin{tabular}{|l|c|c|c|}
\cline { 2 - 4 } \multicolumn{1}{l|}{} & Hin & Avg & Max \\
\hline 1.Customer Order Lead-time (days) & 4 & 8 & 15 \\
\hline $\begin{array}{l}\text { 2.Customer Order Estimation Lead- } \\
\text { time (days) }\end{array}$ & 1 & 1 & 1 \\
\hline $\begin{array}{l}\text { 3.Production Order Release Lead- } \\
\text { time }\end{array}$ & 21 & 28 & 35 \\
\hline 4.Production Order Lead Time & 1 & 2 & 3 \\
\hline 5.Processing Time (hours) & 0.5 & 2 & 4 \\
\hline 6.Shipment Lead Time & 1 & 1 & 1 \\
\hline 7.Transportation lead-time (days) & 1 & 1 & 2 \\
\hline 8.Supplier Lead-time (days) & 28 & 28 & 84 \\
\hline P:D Ratio [=(2+3+4+6+7+8)/1] & $\mathbf{1 3 . 2 5}$ & $\mathbf{7 . 6 2}$ & $\mathbf{8 . 4 0}$ \\
\hline $\begin{array}{l}\text { Value Added Ratio (Production) } \\
\text { [=(5/3+4)] }\end{array}$ & $\mathbf{0 . 0 0 3}$ & $\mathbf{0 . 0 6 6}$ & $\mathbf{0 . 1 0 5}$ \\
\hline
\end{tabular}

These differences in benchmarking data are explained by the fact that ELVAL is a vertically integrated make- to- order manufacturing company while TUBUSMETALL is mainly a trading company servicing customers from semifinished stock by adding one or two final production stages.

Table 5. Results in ELVAL

\begin{tabular}{|l|c|c|c|}
\cline { 2 - 4 } \multicolumn{1}{l|}{} & Min & Avg & Max \\
\hline 1.Customer Order Lead-time (days) & 90 & 90 & 90 \\
\hline $\begin{array}{l}\text { 2.Customer Order Estimation Lead- } \\
\text { time (days) }\end{array}$ & 1 & 1.5 & 2 \\
\hline $\begin{array}{l}\text { 3.Production Order Release Lead- } \\
\text { time (days) }\end{array}$ & 28 & 28 & 28 \\
\hline $\begin{array}{l}\text { 4.Production Order Lead Time } \\
\text { (days) }\end{array}$ & 32 & 32 & 32 \\
\hline 5.Processing Time (days) & 17 & 17 & 17 \\
\hline 6.Shipment Lead Time & 20 & 20 & 20 \\
\hline 7.Transportation lead-time (days) & 7 & 15 & 30 \\
\hline 8.Supplier Lead-time (days) & 15 & 21 & 45 \\
\hline P:D Ratio [=(2+3+4+6+7+8)/1] & $\mathbf{1 . 1 4}$ & $\mathbf{1 . 4 6}$ & $\mathbf{1 . 7 4 4}$ \\
\hline $\begin{array}{l}\text { Value Added Ratio (Production) } \\
\text { [=(5/3+4)] }\end{array}$ & $\mathbf{0 . 2 8 3}$ & $\mathbf{0 . 2 8 3}$ & $\mathbf{0 . 2 8 3}$ \\
\hline
\end{tabular}




\section{CONCLUSIONS}

The above results came out from internal benchmarking procedures within the companies of the REALMS consortium. The next steps in order to put the benhmarking model in the service of business reengineering are the following:

1. Conduct External Benchmarking based on the performance model developed and the internal benchmarking studies. Identify examples of best practices, compare to the existing performance indicators and set targets to be pursued by the reengineering actions.

2. Evaluate reengineering targets. Those targets set in step 1 are usually expressed in the form of operational indicators (e.g. lead times, inventory levels, etc.). Those indicators need to be translated in financial terms, a task which is almost impossible to be handled by traditional cost accounting systems. Activity based Costing (ABC) seems to be here the ideal approach to calculate Return On Investment (ROI) coming from the improvement of such operational indicators.

3. Conduct a simulation study. The simulation tool FEMOS will be used to evaluate reengineering actions in the two pilots. This tool has been developed by the REALMS partner IFAB (TU Karlsruhe, Zuelch 1995) and is particularly suited for evaluating organizational changes. Thus it is hoped that a combination of a priori and a posteriori evaluation of business process reengineering will be possible.

\section{REFERENCES}

Berliner, C. and Brimson, J.A. (Eds.), (1989), Cost Management for Today's Advanced Manufacturing, The CAM-I Conceptual Design, Harvard Business School Press.

Cooper, R. and Kaplan, R.S., (1991), Profit Priorities from Activity-Based Costing, Harvard Business Review, May-June.

Cosmetatos, G., (1996), A Short-Term Profitability based Modelling Approach to Evaluate Changes in Output and in Productivity, REALMS - WP3.

Cosmetatos, G. and S. Eilon, (1983), Effects of productivity definition and measurement on Performance evaluation, European Journal of Operational Research 14, pp. 31-35.

Cosmetatos, G. and Eilon, S., (1981), Analysis of Unit Cost - A Modelling Approach, in: Falster,P. and Rolstadas, A., Production Management Systems, IFIP, North Holland, pp. 167-178.

Doumeingts, G. (1984), Methode GRAI, Methode de Conception des Systemes en Productique, These d' Etat en Sciences, Universite Bordeaux I.

Doumeingts, G., Clave, F. and Y. Ducq, (1995), ECOGRAI - A Method to Design and to Implement Performance Measurement Systems for Industrial 
Organizations, in: Rolstadas, A. (Ed), Benchmarking - Theory and Practice, Chapman \& Hall, London.

Eilon, S. and G. Cosmetatos, (1977), A Profitability Model for Tactical Planning, Omega, Vol. 5, No. 6.

Innes, J. and Mitchell, F.,(1990), Activity Based Costing. A Review with Case Studies, CIMA.

REALMS Consortium, (1996), WP2 - Modelling a Critical Business Process.

Rolstadas, A., (1993), Manufacturing Industry Benchmarking, in: Pappas I., Tatsiopoulos (Eds), Advances in Production Management Systems, NorthHolland.

Tatsiopoulos, I.P., Xerokostas, A.D. and N. Panayiotou, (1996), The Connection of Activity Based Costing to the GRAI Integrated Mathodology for Reengineering Purposes, IFIP WG 5.7 Working Conference Proceedings on Business Modelling, Bordeaux, April.

Theeuwes, J.A. and J.K. Adriaansen, (1994), Towars an integrated accounting framework for manufacturing improvement, Int. J. Production Economics, 36, 85-96.

Zuelch, G., Grobel, Th. and U. Jonsson, (1995), Indicators for the Evaluation of Organizational Performance, in: Rolstadas, A. (Ed), Benchmarking - Theory and Practice, Chapman \& Hall, London.

\section{BIOGRAPHY}

ILIAS P. TATSIOPOULOS is an Asst. Professor in Production Management and Logistics at the Industrial Management and OR Section of the National Technical University of Athens (NTUA). He is also Vice-Chairman of the Greek Institute for Production Management (HMA) and a member of the Greek State Committee for Purchasing. He has been active for several years as a professional production engineer in both industrial and consulting firms and he served as a Lecturer in management information systems at the Economic University of Athens. He studied Mechanical and Industrial Engineering at NTUA (1978) and followed post-graduate studies at the TH Aachen (Germany) and the University of Lancaster (UK) under a NATO grant. He holds a PhD (1983) in Operational Research from the University of Lancaster. 